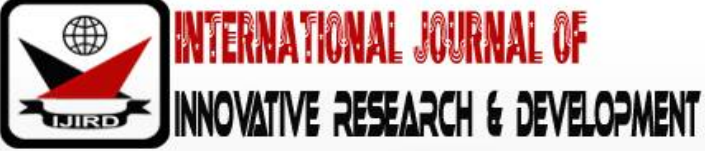

ISSN 2278 - 0211 (Online)

\section{Primary School Teachers' Knowledge and Attitudes to Waste Disposal in Egbeda Local Government, Oyo State, Nigeria}

\author{
Olufiropo Emmanuel Alalade \\ Lecturer, Department of Social Studies, Federal College of Education ( Special), Oyo, Nigeria
}

\begin{abstract}
:
Awareness and declarations about the environment are not enough; concrete steps and practical actions need to be taken to involve the citizens, both young and old, in the care and conservation of the environment. Therefore, this study investigated primary school teachers' knowledge and attitudes to waste disposal. The results of the study showed that teachers in the area of study had adequate knowledge of problems associated with waste disposal and issues of environmental management; the two groups of respondents had favourable attitudes toward waste disposal but the female were more inclined to the various positive steps taken at waste management; and environmental education in schools has been seen as a means of alleviating the problems caused by people's nonchalant attitude towards issues of environment management and waste disposal. Recommendations were also made based on the findings.
\end{abstract}

Keywords: Waste disposal, environmental education, environmental knowledge environmental attitude

\section{Introduction}

\subsection{Background to the Study}

Environment is a broad concept. It refers to all or part of an object's or a living being's surrounding. It becomes everything that surrounds man hence, everything that is used by man including man himself. It includes the physical, chemical, biological, psychological and socio-cultural dimensions and in fact everything that makes up the context in which the individual lives. Environment is not a residual, but an entity which incorporates attitudes, values, institution economic, science and technology and ideology. In general, the environment provides all life support systems in the air, on water and on land as well as the materials for fulfilling all developmental aspirations. A wave of serious concern about the environment has swept across the world. In the past few years, the report of the United Nations Environmental Programme's (UNEP) complimentary report on the "Environment Perspective to the year 2000 and beyond" heralded a new awareness about the close linkage between environment and economic growth. Environment has now become the central issue in discussions at the United Nations General Assembly.

But awareness and declarations are not enough. Fewer words and more actions are needed. There are glaring evidences of pollution and environmental damage prevalent in Nigeria and the world all over either through preventable acts of man, or as a result of natural disasters. This is substantiated by Karlin (2014) that human behavior can impact environmental sustainability significantly. These acts of man include, among others, the uncontrolled discharge of harmful industrial wastes, untreated human sewage; industrial and household refuse into drains, streams, rivers, lagoons, and shoreline. Others are the damage done to the fragile tropical soil through poor land use and unsound agricultural practices; uncontrolled deforestation, forest fires and bush burning. There is also the rapid southerly advance of the desert, aggravated by the uncontrolled felling of trees to provide fuel and wood, and the overgrazing of pasture lands (Ajitoni, 2005).

Apart from these man-induced environmental problems, natural disasters, particularly floods, landslides, tornadoes, coastal and land erosion take their toll.

Waste management, which is one of the major issues highlighted earlier, is a serious problem worldwide. This is particularly so in many industrialized nations like Japan where the combination of dense population, productive economy and limited landfill space exacerbate the situation. In big industrialized countries like the United States of America, Australia, Germany and Britain, municipal governments are the bodies that grapple with the various aspects of waste management that include collection, transfer and disposal (Ayakoha \& Ighoeli, 1997).

It should be noted that the much talked about greenhouse effect is fuelled by inordinate discharges of carbon dioxide, hydrocarbons, and other chemical compounds (Ajitoni, 2005). Furthermore, the ozone hole widens as releases of chlorofluoro-carbons increase; and the forests and oceans are threatened by poisons of man's emissions that are the subject of this research are not invisible chemical compounds. Rather, they are bulky, toxic wastes that are too often 
dumped in various corners of the streets, in ponds behind manufacturing plants, carted to landfills or incinerators or thrown into garbage behind the kitchen (Ayakoha, 1991).

In Nigeria a visit to the sprawling cities will show clearly the effect of rapid urbanization on waste management. In Lagos State, for example, waste management has become a major problem within the past three decades. The ruralurban migration has continued unabated and has resulted in overcrowding and the development of slums that pose serious problems to waste generation and sanitation. McGranahan (2005) has noted that ineffective waste management in cities and towns like Ibadan, Lagos, Kano, Port Harcourt, Aba, Kaduna, and Maiduguri has resulted in degraded urban environment.

McGranahan (2005) has observed further that waste accumulating in the neighbourhood raises more serious problem than at the dumps. Human excreta are the major toxic pollutant and unsanitary conditions at home are more threatening than industrial pollution. The heaps of undisposed waste in unsightly and unauthorized areas breed mosquitoes, flies, cockroaches, and rodents. These, in turn have led to outbreak of diseases such as malaria, cholera, diarrhea and typhoid fever (Ologhobo, 1995). A World Health Organisation (2012) report claims that 23\% of all global deaths are linked to the environment; roughly12.6 million deaths annually.

In the face of all these problems, it has been found that methods of waste disposal in Nigeria are not in any way well defined (Adelabu, 1998). In Ibadan, which is by far one of the fastest growing cities in Nigeria, the solutions most easily implemented in top-down fashion by the government are those characteristics of rich neighbourhoods. These include articulated sewage systems, piped water, door-to-door garbage collection housing standards, and so on (Mc Granahan, 2005). Such systems do not require the households served to have a good understanding of environmental issues, or to participate significantly in environmental management. They are rarely the most appropriate solutions technologically, and often intensify citywide environmental impacts.

\subsection{Objective of the Study}

The issue of waste management in Nigeria has become a national dilemma, which touches on the lives of all and sundry. A filthy environment poses great threat to public health. Ibadan, the capital of Oyo State, is an ancient city compared to other cities in Nigeria. The city is made up of eleven Local Governments Areas (LGAs), five of which are in the urban centre, while the remaining six LGAs are in the peri-urban centre. These LGAs are expanding and increasing in population with a corresponding increase in waste disposal. Some cities in Nigeria like Lagos, Kano and Port Harcourt, among others, are still grappling with waste problem due to ineffective waste management policies and inability to evolve the necessary waste management processes. Ibadan city also suffers from these inabilities hence the need to view other avenues towards creating awareness about the hazards posed by wastes in the society through formal education.

As a necessary step in this direction, this study investigated primary school teachers' knowledge and attitude to environmental issues in Egbeda Local Government Area, one of the eleven Local Government Areas of Ibadan, in Oyo State. The study also examined the differences, if any between male and female teachers, knowledge and attitude to environmental issues and wastes disposal in the Local Government Area.

\subsection{Research Questions}

This study will specifically be sought to answer the following research questions

- What is the level of knowledge of male and female primary school teachers in Egbeda Local Government Area in respect of environmental issues and waste disposal?

- What are the attitudes of male and female primary school teachers towards environmental issues in Egbeda Local Government Area?

- What are the attitudes of male and female primary school teachers to the introduction of Environmental Education (EE) in schools and in the community?

\subsection{Purpose of the Study}

Many people feel today that awareness of environmental degradation has come too late because of much of the damage already done to the ecosystem is irreversible. However, other opinions feel that this permission is unjustified because ecosystems have enormous powers of recovery from traumatic experiences. This study, therefore, investigated the relative awareness of male and female primary school teachers about environmental problems and issues and their practices relative to waste disposal in Egbeda Local Government Area of Oyo State. This was with a view to making recommendations for ways of saving the environment from further spoliation and degradation.

\section{Literature Review}

\subsection{Concept of Waste}

Waste, as the term implies, is any solid liquid, or gaseous substance or material which, being a scrap or being superfluous, refuse, or rejected, is disposed of or required to be disposed of as unwanted. Lagos State Environmental Sanitation Edict 1985 section 32 defines waste as: Any substance which constitutes scrap material or effluent or other unwanted surplus substance arising from the application of any process.

World Health Organization. (2012) defines waste as something which the owner no longer wants at a given time and place and which has no current perceived market value. In its definition, WHO has introduced two elements, "unwanted" and "value". Identifying waste on the bases could be problematic as one person's waste could be another person's raw material. 
Egunjobi (2008) defines waste as that which is cheaper to throw away than to make further use of... the emphasis of this definition does not mean that waste is valueless; some of it is certainly not. This definition of waste is inadequate because it concerns only one user, as it might be economic for him to throw something away but uneconomic for the nation or for mankind in the long run. Adelaja (2008) offers another definition when he observed that waste consists of materials which are not prime products and which can arise from two sources, one category arising from production or manufacture of things we need to sustain our standard of living and the other is generated by discarding the things we have made and used. This study agrees with this definition as it emphasizes the point that waste is not a prime product.

\subsection{Concept of Waste Management}

Egunjobi (2008) reported that wastes generation by the Nigerian city inhabitants grows in the same proportion as the cities grow. Indeed, there is a strong positive correlation between population growth and volume of solid wastes generation in any country's urban areas and cities. The expression "waste management" simply means the collection, keeping, treatment and disposal of waste in such a way as to render them harmless to human and animal life, the ecology and the environment generally. Proper waste management also involves the after care of sites and the equipment used in the management of waste, as well as the: source reduction, reuse of products, recycling and solid waste disposal.

Effective waste management requires the use of a variety of waste disposal practices to safely handle the household waste stream. This requires an integrated approach, the combination of a number of technologies including source reduction, recycling, composting, sanitary landfill, incineration, combustion and pyrolysis. Using the integrated approach does not mean all these options are to be implemented, but it presents options for individuals and communities to consider. The methods are environmentally friendly and could be relied upon to promote public health.

\subsection{Problems of Waste Management in Nigeria}

A number of reasons have been advanced as factors responsible for the inefficiency of the existing systems of urban solid waste management. Among these reasons are lack of designated waste collection site, shortage of personnel, institutional relations, the city structure, lack of infrastructure, lack of equipment and the inability of the business sector to utilize waste materials optimally, and lack of adequate waste collection sites. In urban areas, many people out of desperation dispose their waste in gutters, drainages, streams and rivers owing to lack of designated collection sites. The waste materials so deposited clog up blocking waterways causing flood during rainy season. For example, the Ibadan flood disaster of 2011 was caused by waste blocking the water channels. It is necessary that waste is properly collected and disposed off so that drainages are not blocked and the environment is not polluted.

Uncollected waste from dump sites provides the breeding ground for flies, cockroaches, rats and rodents. These pests easily transmit diseases that can greatly affect human health. The waste can also pollute the underground water resources especially during water percolation processes. At times waste contaminates potable water thus rendering it unfit for human consumption. Those who ignore the pollution and consume the water are easily attacked by cholera, dysentery, diarrhea, typhoid fever, yellow fever, malaria and river blindness.

Solid wastes are probably the most visible forms of pollution. Man throws away billions of tons of solid material each year. Much of the wastes end up littering roadsides, floating in lakes and streams, and collecting in ugly dumps. Examples of solid wastes include junked automobiles, tyres, refrigerators, cans and other packaging materials, and scraps of metal and paper. Solid wastes present a serious problem because most of the methods used to dispose of them result in some type of damage to the environment:

- When the wastes are out into open dumps, they ruin the aesthetics of the surrounding areas.

- Dumps also provide homes for disease-carrying animals, such as cockroaches and rats.

- Some solid wastes can be destroyed by burning them, but burning produces smoke that causes air pollution

- When wastes are dumped in water, they contribute to various forms of water pollution.

Johnson (2010) listed fire hazard, communicable diseases, contamination of the underground water, and pollution of the landscape, urban flooding, unsightliness and odour nuisance as part of the major environmental consequences of ineffective solid wastes management practices in Nigeria.

Johnson (2010) suggested some solutions to problems of solid waste management in Nigeria:

- There must be an established effective management information system to aid planning, decision-making and control;

- In ensuring household storage of solid wastes, suitably adapted plastic and galvanized metal bins may be used. The cost of these may be subsidized to enable them to be within the reach of every householder;

- Disposable household paper or plastic bags may be introduced and the local production of these, at cheaper prices to households, can be encouraged;

- Emphasis must be laid on house-to-house solid wastes collection services;

- Despite the fact that the use of communal collection service for solid wastes management is evidenced in Nigerian most cities, yet it is recommended that no user, where communal facilities exist, must have to carry solid wastes for more than 150 metres to the depot;

- For adoption of other more sophisticated storage appliances there is need to consider implications of these in respect of costs, available skill and general practicality of maintenance;

- To make solid wastes transportation easier, it is necessary to relate the type and size of vehicular units required to operating factors, namely, the nature of the solid wastes, haulage distance, and the traffic situation; 
- Any decision on the types of vehicles to be purchased for solid wastes transportation must be accompanied either with a strong and legally binding after-sales service agreement, or with a decisive programme of training local staff to do the servicing;

- The three systems of waste disposal in practice are landfill, incineration and composting. At present, the most commonly acceptable is sanitary landfill;

- The selection, operation and design of the landfill should be based on a systematic integrated study and an evaluation of all physical conditions, economic and socio-political constraints as well as required equipment for the various operations;

- For small urban communities, non-mechanical composting techniques appear beneficial, while mechanical technique is considered suitable for large urban centres. The former technique is labour-intensive while the latter is capital-intensive;

- There should be original and adaptive research development in designing correct equipment for dealing with all areas of environmental activities, including solid wastes;

- In the annual operational budget for solid wastes management, special attention must be paid to maintenance costs of vehicles, plant and equipment to ensure for these a high and efficient availability ratio; and

- The enacted environmental protection law should be enforced with sincerity.

\section{Methodology}

The research design adopted in this study is an expost facto descriptive survey design. The design was used to study, through the questionnaire, the knowledge attitudes and practices of teachers toward waste disposal.

\subsection{Population, Sample and Sampling Technique}

The target population for this study was the primary school teachers in Egbeda local government are of Oyo State. A total of 10 primary schools were selected from the population and then studied. The random sampling technique was adopted in the process. 10 teachers were selected in each school making a total of 100 teachers.

\subsection{Data collection}

The instrument used to collect data from the respondents was the Waste Disposal Knowledge, Attitudes and Practices (WADKAP) questionnaire. the researcher visited all the schools used for the study in the local government area to administer the questionnaire. the questionnaires were immediately collected after completion.

\subsection{Validity and Reliability}

The split half employing the Spearman-Brown formula for modification was used to test the reliability of the instrument. In measuring the reliability of the WADKAP, the scores of the odd items were assigned to the other half of the instrument. Each sample was then treated as a separate sub-test and the individual respondent then had two scores on an instrument. The two sets were then correlated and the coefficient of correlation ( $\mathrm{r}$ ) was found to be 0.72 .

To determine the validity of the WADKAP, the answers provided by the respondents were carefully examined to determine the difficulty index and the discrimination index of the items

\section{Results and Discussion}

Research question 1: What is the level of knowledge of male and female primary school teachers in Egbeda Local Government Area in respect of environmental issues and waste disposal?

\begin{tabular}{|c|c|c|c|c|c|c|}
\hline Variable & $\mathbf{N}$ & $\mathbf{X}$ & S.D & Obs.T & Tabl. T & DF \\
\hline Male & 47 & 77.0 & 8.4 & & & \\
\cline { 1 - 3 } Female & 53 & 84.7 & 13.9 & 0.3 & 1.980 & 98 \\
\hline
\end{tabular}

Table 1: Summary of Analysis of Difference in Teachers' Knowledge of

Environmental Issues and Waste Disposal

Table I shows the summary of the analysis of difference in male and female teachers' knowledge of environmental issues and waste disposal. The female group showed a higher mean score of 84.7 to the mean score of 77.1 to their male counterparts. Therefore, there was a significant difference in the knowledge possessed by the female and the male teachers as regards environmental issues and waste disposal. A clear evidence that the female folk were much concerned with keeping the environment neat and tidy.

- $\quad$ Research question 2: What are the attitudes of male and female primary school teachers towards environmental issues in Egbeda Local Government Area?

\begin{tabular}{|c|c|c|c|c|c|c|}
\hline Variable & $\mathbf{N}$ & $\mathbf{X}$ & S.D & Obs. T & Tabl. T & DF \\
\hline Male & 47 & 76.9 & 7.9 & & & \\
\hline Female & 53 & 80.9 & 10.8 & 0.3 & 1.980 & 98 \\
\hline
\end{tabular}


Table 2 shows that both male and female respondents had favourable attitudes towards waste disposal in the area under study. But the females were however seen to be more inclined to the various steps taken at waste management with mean score of 80.9 against 76.9 for their male counterparts. Furthermore, the standard deviation showed a significant difference in the attitudes of female subjects (S.D 10.8) and those of the male subjects (S.D 7.9).

Research question 3: What are the attitudes of male and female primary school teachers to the introduction of Environmental Education (EE) in schools and in the community?

\begin{tabular}{|ll|c|c|c|c|}
\hline \multicolumn{2}{|c|}{ Variable } & N & X & S.D & DF \\
\cline { 1 - 4 } 1. & Male & 47 & 88.4 & 10.0 & \multirow{2}{*}{98} \\
\hline 2. & Female & 53 & 93.7 & 13.5 & \\
\hline
\end{tabular}

Table 3: Summary of Respondent's Attitude to the Introduction of EE

From Table III it can be seen that both male and female respondents had favourable disposition toward the introduction of Environmental Education (EE) into schools to help curb the problems of created by man in respect of waste management. The mean score of the male respondents was 88.4 while that of the female was 93.7. As a matter of fact, even before the advent of Western education, there had been some form of awareness and protection measures among the indigenous peoples of Nigeria as expressed in protection of forests around water sheds and shrines, sanitation and discrete waste disposal. Thus, the response of the subjects to Environmental Education and awareness programmes was very positive.

\section{Summary of Findings}

From the findings of this study, the following conclusions can be drawn;

1. Male and female teachers in the area of study had adequate knowledge of problems associated with waste disposal and issues on environmental management.

2. The two groups of respondents had favourable attitude towards waste disposal but the female was more inclined to the various positive tests taken at waste management.

3. Environmental Education in schools has been seen as a means of alleviating the problems caused by people's nonchalant attitude towards the issues of environmental management and waste disposal.

\section{Discussion}

A healthy and beautiful environment is not a luxury but a basic human need both materially and otherwise. It is known to influence individual and community development because development evolves from people's increasing ability to utilize the environment and its resources in the production of needed goods and services. Sustainable development calls for the efficient management of the environment includes, among other things, informed and effective practices of generation and disposal of wastes, in both public and private premises.

The people in the sampled area had adequate knowledge of waste prevalent in the communities and the hazards posed by such wastes from their environment. However, their practices relative to waste disposal were not very encouraging.

Moreover, the findings have shown the lack of government presence in terms of the provision of dumpsites and trucks or other means for evacuating household solid waste to government approved dumpsites.

\section{Recommendations}

Achieving effective waste generation and disposal in schools and in private premises is a task that must be accomplished, and this calls for enhanced commitment on the part of individuals, households, organisations, and government.

- Government should commit more funds towards waste management in both the urban and the rural centres. Such funds should be used for the provision of necessary facilities such as vehicles, and for the regular maintenance.

- Environmental Education should be introduced into the school curriculum, and there is the need to educate the public on proper waste generation and disposal practices, includes, including the sorting of waste and the correct use of dumpsites

- Schools and households should teach children on how to handle wastes effectively.

\section{References}

i. Adelabu, M. (1998). Urban Schools in Waste management. In S. S. Obidi, E. R. I. Afolabi,

ii. M. Adelabu (Eds.), Book of readings on education, environment and sustainable development. Ibadan, Nigeria: Cardinal Crest.

iii. Adelaja, A. O. (2008). Inter-sectoral linkage between water, sanitation and hygiene education. Apaper presented at the sanitation workshop organized by the Federal Ministry of Health, Abuja, 13-16 November, pp.1-10.

iv. Ajitoni, S. O. (2005). Effects of full and quasi-participatory learning strategies on Senior Secondary students' environmental knowledge and attitudes in Kwara State, Nigeria. (An unpublished Ph.D. thesis). University of Ibadan, Ibadan, Nigeria.

v. Ayakoha, E. U. (1991). Home management for schools and colleges. Enugu, Nigeria: FEP publishers. Ltd.

vi. Ayakoha, E. U. and Ighoeli, C. C. (1997). Household solid waste disposal practices of women in Nigeria. Enugu, Nigeria: African FEP publishers ltd. 
vii. Egunjobi, L. (2008). Waste management and environmental care. A city approaches. Paper presented at the training of trainer's workshop on planning and management system and environmental care at Ibadan Solid Waste Management Authority, November 18-19, pp, 1-4.

viii. Inyang-Abia, M. E. (1994). Formal dimensions of the Green Campaign. Calabar, Nigeria: University press.

ix. Johnson, D. D. (2010). Environmental degradation, its impact on infant/ childhood death in Nigeria: options for effective control". In D. Okali, et al. (ed) Perspective for environmental management (27-34). Ibadan: NEST.

x. Karlin, B. M. (2014). "Attitudes and Behaviors." In Rowe, D. (Ed), Achieving Sustainability: Visions, Principles, and Practices (40-44). Detroit: Macmillan Reference.

xi. McGrahanan, S. (2005). Towards sustained development in Africa. Washington DC, USA.

xii. Ologhobo, A. (1995). Strategies for efficient waste disposal in Nigeria. Ibadan, Nigeria: NEST publications.

xiii. World Health Organization. (2012). Our planet, our earth, our future. Geneva: WHO press. 